\title{
Cognitive Emotion Theory and Emotion-Action Tendency in Online Impulsive Buying Behavior
}

\author{
Muhammad Danish Habib * $\quad$ Abdul Qayyum ${ }^{\dagger}$
}

\begin{abstract}
Impulsive buying in online setting has become an epidemic as it represents a noteworthy proportion of online shopping. Impulsive buying behaviors with upcoming avenues for future research are under the constant considerations of academicians and practitioners. Despite abundant research on impulsive buying behavior in online context, research scholars demand for further research and empirical evidences for better understanding of the phenomenon. It is therefore worthy question to examine impulsive buying behaviors in online setting. This study seeks to model and empirically examine cognitive aspects as a precursor of emotional aspects that ultimately lead towards impulsive buying actions. This study used cognitive emotion theory and emotion-action tendency to model impulsive buying behavior in online context. Specifically, this study seeks to examine key cognitive aspect (ease of use, informativeness, perceived risk and perceived trust) and emotional aspects (pleasantness and arousal) on impulsive buying actions (web browsing and urge to buy impulsively). A total of 317 survey responses from shoppers of online stores were collected with the help of convenience sampling technique. To empirically test the measurements and propositions, structural equation modelling approach was used. From the results a significant model was emerged. In general results were in support of the assertions that cognitive aspects lead toward emotional aspects that resulted in impulsive actions. This study contributes to the literature of decision making, online retailing and e-commerce marketing. This study offers valuable insight and solid grounds to academicians as well as practitioners concerning online impulsive buying behavior by presenting empirical findings and important implications.
\end{abstract}

Keywords: Cognitive aspects, emotional aspects, web browsing, urge to buy impulsively, online shopping

\section{Introduction}

Impulsive buying is regarded as a multifaceted buying behavior characterized by spontaneous, compelling and unplanned urge for immediate possession, with no or little evaluation of purchase or its consequences (Chan, Cheung, \& Lee, 2017; Lucas \& Koff, 2017; H. J. Park \& Dhandra, 2017). Facts concerning impulsive buying revealed a significant proportion of consumer buying is attributed to unintended and unreflective purchases (Bellini, Cardinali, \& Grandi, 2017). For instance 30-50\% sales at retail store (Hausman, 2000 ); $62 \%$ sales in super markets and about $80 \%$ sales in luxury products (Ruvio \& Belk, 2013) are recorded as impulsive purchases. Furthermore, Merzer (2014) based on the sur-

\footnotetext{
* PhD Scholar, Department of Management Sciences, Shaheed Zulfikar Ali Bhutto Institute of Science and Technology, Islamabad. E-mail: danish.habib87@gmail.com

${ }^{\dagger}$ Assistant Professor, Department of Management Sciences, Riphah School of Leadership, Riphah International University, Islamabad Pakistan. E-mail: abdul_qayyum@hotmail.com
} 
vey of US customer found 3 out of 4 (i.e.75\%) respondents reported an impulse purchase. The proliferation of online shopping has arose the profound potential of impulse buying phenomena in online context (Lin \& Lo, 2016). For instance, Brashear, Kashyap, Musante, and Donthu (2009) asserted that internet shoppers are relatively more inclined towards impulsive buying than those in conventional retailing. Furthermore, research scholars of information systems are interested in exploring the methodologies for the identification of factors that may lead towards online impulse buying (Parboteeah, Valacich, \& Wells, 2009).

Online impulsive buying behaviors not only offers a plentiful avenues for marketing scholars interested in decision making processes and consumer behaviors, but also is focus of interested of practitioners as it accounted for significant amount of profits for firm. A rich literature can be found among the existing studies concerning online impulsive buying behavior. Chan et al. (2017) identified two major streams of research with reference to impulsive buying behavior. First stream focuses on website cues like website characteristic (Parboteeah et al., 2009); value-added search mechanism (Koufaris, 2002); media formats (Adelaar, Chang, Lancendorfer, Lee, \& Morimoto, 2003); functional convenience and representational delight (Verhagen \& van Dolen, 2011). Second focuses on the role of offline impulse-buying factors in driving online impulsive buying behavior for example role of marketing promotion tactics (Dawson \& Kim, 2009); role of hedonic consumption needs (Chih, $\mathrm{Wu}, \& \mathrm{Li}, 2012)$. The diverse theoretical perspectives have been used to explain the online impulse-buying behavior for instance S-O-R framework is recognized as of the most popular theoretical perspective used to explain online impulsebuying behavior in the last decade (Floh \& Madlberger, 2013; Liu, Li, \& Hu, 2013). Some other theoretical approaches such as cognitive emotion theory (Verhagen \& van Dolen, 2011); reflective-impulsive mechanism (Ning Shen \& Khalifa, 2012) and flow theory (Hsu, Chang, \& Chen, 2012) are used to explain the phenomenon of online impulsive.

A plethora of literature available on impulsive buying behavior in online context, in spite of this recent studies call for future research to delve into impulsive phenomenon for better understanding (Bellini et al., 2017; Chan et al., 2017; Lucas \& Koff, 2017). Liu et al. (2013) is with the view point that integration of marketing wisdom and information systems would enrich the literature of online impulse buying behavior. Accordingly, examination of unplanned consumer behavior that is impulsive buying in online context may provide a valuable insight and solid grounds to the existing body knowledge of online impulsive buying behaviors. In a meta-analysis on online impulsive buying, (Chan et al., 2017) demand for more empirical evidences as the present empirical findings are insufficient for a comprehensive meta-analysis.

Richard and Chebat (2016) also call for future research to model and empirically test the key cognitive website use variable like informativeness, entertainment and purchase intentions in online setting context. Since impulsive buying is recognized as relatively irrational as compared to normal purchase behavior, and mainly derived from external stimuli. Thus, to delineate the antecedents used by online retailers to evoke online impulse buying and effects of external stimuli (e.g. easy to use, usefulness and informativeness) on emotional state (arousal and pleasantness), are in need of further examination (Lin \& Lo, 2016). It is then a worthy research avenue to model and empirically test 
key cognitive and emotional variables that evoke online impulsive purchase through web browsing. Derived from the Cognitive Emotion Theory (Verhagen \& van Dolen, 2011) and Emotion Action Tendency (Dholakia, Bagozzi, \& Pearo, 2004) this research attempts to examine the impact of cognitive variables (ease of use, informativeness, , perceived risk and perceived trust) on impulsive actions (web browsing and urge to buy impulsively) through emotional response (arousal and pleasantness) in online setting. This research contributes in marketing as well as consumer behavior literature more specifically in decision support literature by elucidate impulsive buying behavior in online context.

\section{Literature Review}

Impulsive buying behavior is considered as an unintended and unreflective urge to buy a specific product or band evoked in repose of a stimulus (Chan et al., 2017). This spontaneous and powerful urge to buy has been related to a number of factors that can be categorized under two major streams as market driven factors and individual led factors (Haq, Abbasi, et al., 2016). The former probed into the external factors such as product related factors or situational factors along with the differentiation in impulse and non-impulsive buying and categorization of impulsive buying. The later look into the consumer psychology and that leads toward behaviors. First research stream aimed to differentiate the concept of impulsive buying and planned buying and try to figure out the product related characteristics that may lead towards an impulse purchase (J. Park \& Lennon, 2006). Later research stream examined the placement of stimulus to elevate product design, appearance and style for example attractive product display or innovative packing (Hubert, Hubert, Florack, Linzmajer, \& Kenning, 2013). Furthermore, situational factors such as atmospheric cues (Floh \& Madlberger, 2013); services quality (Pornpitakpan, Yuan, \& Han, 2017); social influences (Amos, Holmes, \& Keneson, 2014); economic wellbeing, time and money (Badgaiyan \& Verma, 2015) were also found as contributing factor towards impulse buying behavior. Amos et al. (2014), a meta-analysis of consumer buying behavior suggested that interplay of dispositional, situational and sociodemographic aspects can be designed for designing a suitable environment for impulsive buying. On the other hand, Verplanken and Sato (2011) argued that examination of functioning related to psychological aspects specifically self-regulation can be useful for better insight of impulsive buying behavior.

Consumer unintended and spontaneous purchase might be derived from the simplicity or complexity of the website layout (Wu, Chen, \& Chiu, 2016). This view point supported the assertion that consumer purchase behavior is a result of emotional, low cognitive control and spontaneous reaction (Sharma, Sivakumaran, \& Marshall, 2010). This perspective tend to advocate that appealing object evoke impulsive buying behaviors, in the extension of impulse buying episodes scholars credited online shoppers as more spontaneous than traditional shoppers (E. J. Park, Kim, Funches, \& Foxx, 2012). Marketing stimuli can develop a scene of risk aversion during initial search of shoppers and lead towards purchase impulsively (Chung, Song, \& Lee, 2017).

A number of studies explore a variety of variables in developing impulsive buying 
behavior. For instance, research studies examine the influence of cognitive aspects (e.g. ease of use, enjoyment, perceived risk, perceived trust) and affective aspects (e.g. product affect) on impulsive buying (Verhagen \& van Dolen, 2011; Vonkeman, Verhagen, \& van Dolen, 2017). Adelaar et al. (2003) examine the impact of media formats (i.e. video, still images, and text) on impulsive buying behavior.

Hypothesis 1: Ease of use has a significant and positive impact on emotional response.

Hypothesis 2: Informativeness has a significant and positive impact on emotional response.

Hypothesis 3: Perceived trust has a significant and positive impact on emotional response.

Hypothesis 4: Perceived risk has a significant and positive impact on emotional response.

Furthermore, Wells, Parboteeah, and Valacich (2011) studied the role of web site quality and personal trait on urge to buy impulsively. Additionally, Floh and Madlberger (2013), on the reflection of S-O-R model studied the how web site navigation and atmospheric cues contributes in impulsive buying through shopping enjoyment. Moreover, Turkyilmaz, Erdem, and Uslu (2015) pointed out the significance of web site personality characteristics and argued that emotional and informational web contents leads towards web browsing that resulted in online impulsive buying behavior (Rezaei, Ali, Amin, \& Jayashree, 2016).

Hypothesis 5: Emotional response has a significant and positive impact on web browsing.

Hypothesis 6: Emotional response has a significant and positive impact on urge to buy impulsively.

Hypothesis 7: Web browsing has a significant and positive impact on urge to buy impulsively.

\section{Theoretical Framework}

The theoretical model is depicted in Figure 1, drives from the reflections of Cognitive Emotion Theory (CET) and Emotion-Action Tendency (EAT) link which are rooted in impulsive buying literature. Following the conceptualization of above-said theories like stimulus and its consequent formation causes emotion (CET) which led to impulsive action tendencies (EAT) and thus to an impulsive action (Haq et al., 2016; Verhagen \& van Dolen, 2011). So it was proposed that key cognitive variables (ease of use, informativeness, perceived risk and perceived trust) turn into impulsive actions (web browsing and impulsive buying behavior) by generating emotional response (pleasantness and arousal). 


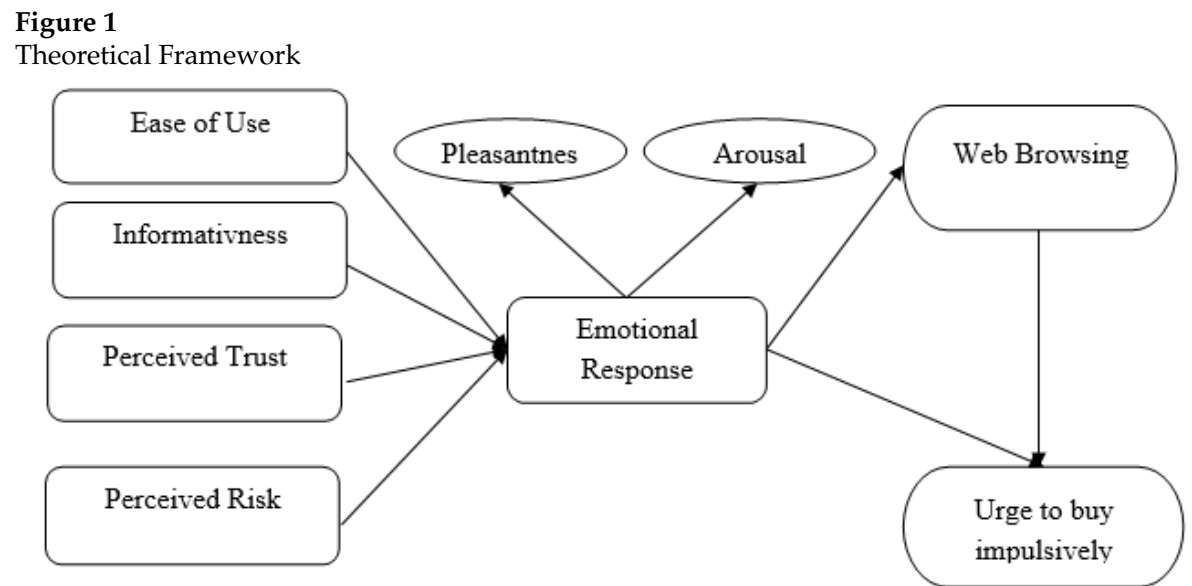

\section{Methodology}

A quantitative research method was designed to empirically scrutinize the theoretical model and to examine the theorized relationships between variables. Questionnaire survey method was employed to collect data from the sample, questionnaire was developed by adapting scale from the existing literature of impulse buying.

\section{Sample and Measures}

Population of the study was online purchasers and consumers of online stores such as telemart, kaymu, daraz, lootlo, ishopping and pakstlye were selected as the sample, overall 317 respondents provided utilizable responses. As per Morgan and Krejici (1970) formula 285 responses are enough when the population is unknown and propositions are tested on the bases of population proportion expressed as $0.5(50 \%)$ with $95 \%$ confidence of internal and margin of error at 5\% (0.05).

To collect the data regarding to online impulse buying from shopping websites, three sections were designed. The first section was about the screening question to ensure that respondents have experience an online buying from shopping websites during last three months. Second section was designed to collect the data for study variables. Multiple items from existing validated scales were adopted to measure the constructs. Last section was designed to collect the information regarding respondents profile for instance gender, age, education and monthly income. Ease of use was measured on four, web browsing on three and urge to buy impulsively on four items adopted from Verhagen and van Dolen (2011). Informativness was measured on four items adapted from Richard and Chebat (2015). Perceived risk was measured on three and perceived trust was measured on four items scales adapted from Mortimer et al., (2016). Emotional response was measured as second order construct consisted of two dimensions that are pleasantness and arousal. 
Pleasantness and arousal was measured on three items each adapted from Lin and Lo (2016).

\section{Data Analysis}

Current study aimed to empirically examine the validation of measures and proposed rational paths, in order to accomplish aforementioned purpose a series of analysis were conducted.

\section{Demographic Analysis}

Total of 400 questionnaires were floated out of which 317 usable responses (response rate of $86.6 \%$ ) were returned, and this response was quite good and consider adequate for further analysis. The frequency distribution showed in Table 1 represented that $78.06 \%$ percent respondents were male and $21.94 \%$ were female. $4.1 \%$ respondents were below the age of $25,29.3 \%$ respondents were of age group 26 to $30.52 .7 \%$ were of age group 31 to 35 and $13.9 \%$ were above the age of 36 . Out of 317 respondents, $62.1 \%$ had Graduation, $29.7 \%$ had Masters and only $8.2 \%$ had M.Phil/ PhD. Income profile of the sample indicated that $2.5 \%$ were earning below $50,000,29.7 \%$ respondents had the income between 50001 to 100,000 rupee, $40.4 \%$ were earning rupees 100,001 to $150,000,27.4 \%$ were earning above 150,001 .

\begin{tabular}{|c|c|c|}
\hline & & Frequency \\
\hline \multirow{3}{*}{ Gender } & Male & $78.06 \%$ \\
\hline & Female & $21.94 \%$ \\
\hline & Below 25 years & $4.10 \%$ \\
\hline \multirow{4}{*}{ Age } & 26 to 30 years & $29.30 \%$ \\
\hline & 31 to 35 years & $52.7 \% \%$ \\
\hline & ? 36 years & $13.90 \%$ \\
\hline & Graduation & $62.10 \%$ \\
\hline \multirow[t]{3}{*}{ Education } & Masters & $29.70 \%$ \\
\hline & M.Phil/ PhD & $8.20 \%$ \\
\hline & Below 50,000 Rupee & $2.50 \%$ \\
\hline \multirow{3}{*}{ Income } & 50001 to 100,000 & $29.70 \%$ \\
\hline & 100,001 to 150,000 & $40.40 \%$ \\
\hline & 150,001 & $27.40 \%$ \\
\hline
\end{tabular}

\section{Measurement Model}

Measurement model was observed to check the fitness of the model and to test the validity and reliability of the scales. AMOS 20 used to conduct the analysis. Before estimating structural model measurement model was estimated and re-specified it for model fit threshold (Anderson \& Gerbing, 1988; Sethi \& King, 1994). Measurement model was evaluated on the bases of Goodness of model fit (model $\left(\chi^{2} / \mathrm{df}, \mathrm{GFI}, \mathrm{AGFI}, \mathrm{NFI}, \mathrm{CFI}\right.$, RMSEA), average variance extracted (AVE) composite reliability and Cronbach's alpha. 
(Chung et al., 2017). The factor loads greater than .50 and AVE greater than .50 were the indication of convergent validity (Hair, Black, Babin, Anderson, \& Tatham, 2013). However, AVE values greater than .40 is acceptable if CR is greater than .60 (Mittal, Chawla, \& Sondhi, 2016). Furthermore Cronbach's alpha greater than 0.7 is an indication of reliability, however Sekaran and Bougie (2016) suggested that the alpha value greater than .60 is acceptable.

Table 2

Measurement model for convergent/ discriminant validity and composite reliability

\begin{tabular}{|c|c|c|c|c|c|c|}
\hline Factor & Measurement Items & Estimate & No of Items & CR & AVE & Alpha \\
\hline EOU & $\begin{array}{l}\text { EOU1 } \\
\text { EOU2 } \\
\text { EOU3 } \\
\text { EOU4 } \\
\end{array}$ & $\begin{array}{l}0.663 \\
0.737 \\
0.726 \\
0.700 \\
\end{array}$ & 4 & 0.800 & 0.500 & 0.798 \\
\hline INFO & $\begin{array}{l}\text { INFO1 } \\
\text { INFO2 } \\
\text { INFO3 } \\
\text { INFO4 }\end{array}$ & $\begin{array}{c}0.706 \\
0.732 \\
0.723 \\
-\end{array}$ & 3 & 0.764 & 0.519 & 0.785 \\
\hline PRSK & $\begin{array}{l}\text { PRSK1 } \\
\text { PRSK2 } \\
\text { PRSK3 } \\
\text { PRSK4 }\end{array}$ & $\begin{array}{l}0.734 \\
0.681 \\
0.613 \\
0.659\end{array}$ & 4 & 0.767 & 0.453 & 0.767 \\
\hline PTRU & $\begin{array}{l}\text { PTRU1 } \\
\text { PTRU2 } \\
\text { PTRU3 }\end{array}$ & $\begin{array}{l}0.642 \\
0.674 \\
0.683 \\
\end{array}$ & 3 & 0.706 & 0.444 & 0.636 \\
\hline PLES & $\begin{array}{l}\text { PLES1 } \\
\text { PLES2 } \\
\text { PLES3 }\end{array}$ & $\begin{array}{l}0.666 \\
0.699 \\
0.667 \\
\end{array}$ & 3 & 0.718 & 0.459 & 0.717 \\
\hline AROS & $\begin{array}{l}\text { AROS1 } \\
\text { AROS2 } \\
\text { AROS3 }\end{array}$ & $\begin{array}{l}0.766 \\
0.807 \\
0.748 \\
\end{array}$ & 3 & 0.818 & 0.599 & 0.814 \\
\hline WEB & $\begin{array}{l}\text { WEB1 } \\
\text { WEB2 } \\
\text { WEB3 }\end{array}$ & $\begin{array}{l}0.760 \\
0.713 \\
0.749 \\
\end{array}$ & 3 & 0.785 & 0.549 & 0.830 \\
\hline UTBY & $\begin{array}{l}\text { UTBY1 } \\
\text { UTBY2 } \\
\text { UTBY3 } \\
\text { UTBY4 }\end{array}$ & $\begin{array}{l}0.608 \\
0.649 \\
0.635 \\
0.683\end{array}$ & 4 & 0.739 & 0.415 & 0.656 \\
\hline $\begin{array}{l}\text { Note 1: } \\
\text { NFI= .8 } \\
\text { Note 2: } \\
\text { Trust }= \\
\text { to Buy I }\end{array}$ & $\begin{array}{l}\text { CMIN = 393.648, CMII } \\
99, \text { CFI= .981, RMSEA } \\
\text { Ease of use = EOU; Inf } \\
\text { PTRU; Pleasantness = I } \\
\text { mpulsively = UTBY }\end{array}$ & $\begin{array}{l}\text { /df }=1.2( \\
0.025 \\
\text { LSmativene } \\
\text { LSE; Arou }\end{array}$ & $\begin{array}{l}\mathrm{p} \leq 0.007 ; \mathrm{df} \\
=\mathrm{INFO} ; \text { Perc } \\
\text { l = AROS; We }\end{array}$ & $\begin{array}{l}=327, \\
\text { eived } \\
\text { b Bron }\end{array}$ & $\begin{array}{l}\mathrm{FI}=.92 \\
\text { sk }=\mathrm{PR} \\
\text { ing }=\mathrm{W}\end{array}$ & $\begin{array}{l}\text { GFI }=.9 \\
\text { Perceiv } \\
\text { and Ur }\end{array}$ \\
\hline
\end{tabular}

Results of model fitness, reliability and validity of the scale illustrated in Table 2 . Initial measurement model was composed of eight latent and 28 observed variables. In respecified model one item from informativeness (INFO4) was dropped due to less factor load. Additionally, the results regarding correlational matrix indicted a strong correlation $(\mathrm{r}=.637)$ between PLES and AROS. For this reason PLES and AROS were re-specified as dimensions of emotional response (ERESP). It is also evident from literature that emo- 
tional response have two primary dimensions: pleasantness and arousal (Groeppel-Klein, 2005; Lin \& Lo, 2016). Therefore in re-specified model emotional response (ERESP) was treated as second order construct which was consisted of two dimensions: pleasantness (PLES) and arousal (AROS).

According to the model fitness indices $(\mathrm{CMIN}=393.648, \mathrm{CMIN} / \mathrm{df}=1.204, \mathrm{p} \leq 0.007$; $\mathrm{df}=327, \mathrm{GFI}=.922, \mathrm{AGFI}=.903, \mathrm{NFI}=.899, \mathrm{CFI}=.981, \mathrm{RMSEA}=0.025)$ measurement model emerged statistically fit. Furthermore, in validity and reliability test, values of factor loading, CR and AVE of constructs were appeared acceptable expect one item of INFO is deleted which shows that scale encompasses the requirement of convergent validity. Additionally, comparison of square root values of AVE with the correlations each construct were made to ensure the divergent validity, in Table 3 squared root of AVE of each contract occurred greater than correlations values of same construct which is an indication of divergent validity. Moreover, in validity test Cronbach's Alpha values of all constructs also meet the threshold limit which verified that scale is internally consistent and reliable.

Table 3

Results of the Fornell-Larcker validation

\begin{tabular}{lcccccccccc}
\hline & AVE & SQRT (AVE) & EOU & INFO & PRSK & PTRU & PLES & AROS & WEBB & UTBY \\
\hline EOU & 0.500 & 0.707 & $-\mathbf{0 . 7 0 7}$ & & & & & & & \\
INFO & 0.519 & 0.720 & -0.024 & $\mathbf{- 0 . 7 2 0}$ & & & & & & \\
PRSK & 0.453 & 0.673 & $-0.579^{* *}$ & $-0.478^{* *}$ & $\mathbf{- 0 . 6 7 3}$ & & & & & \\
PTRU & 0.444 & 0.666 & 0.014 & -0.063 & $-0.410^{* *}$ & $-\mathbf{0 . 6 6 6}$ & & & & \\
PLES & 0.459 & 0.677 & $0.480^{* *}$ & $0.501^{* *}$ & $-0.577^{* *}$ & $0.293^{* *}$ & $\mathbf{- 0 . 6 7 7}$ & & & \\
AROS & 0.059 & 0.774 & $0.399^{* *}$ & $0.521^{* *}$ & $-0.314^{* *}$ & $0.362^{* *}$ & $0.637^{* *}$ & $\mathbf{- 0 . 7 7 4}$ & & \\
WEBB & 0.549 & 0.741 & $0.228^{* *}$ & $0.233^{* *}$ & $-0.339^{* *}$ & $0.166^{* *}$ & $0.262^{* *}$ & $0.396^{* *}$ & $\mathbf{- 0 . 7 4 1}$ & \\
UTBY & 0.415 & 0.644 & $0.504^{* *}$ & $0.359^{* *}$ & $-0.681^{* *}$ & $0.306^{* *}$ & $0.526^{* *}$ & $0.589^{* *}$ & $0.455^{* *}$ & $\mathbf{- 0 . 6 4 4}$ \\
\hline
\end{tabular}

\section{Common Method Variance (CMV)}

Harman's single factor analysis used to examine common method variance biased. Total variance explained by single factor should be less than $50 \%$. Results of CMV test depicted in Table 4, according to facts total variance explained by factor one emerged only $30 \%$ which indicated that data is free of common method variance bias (Tehseen, Ramayah, Sajilan, et al., 2017).

Table 4

Total Variance Explained

\begin{tabular}{|c|c|c|c|c|c|c|c|c|c|}
\hline \multirow[b]{2}{*}{$\begin{array}{l}\text { Factor } \\
1\end{array}$} & \multicolumn{3}{|c|}{$\begin{array}{c}\text { Initial } \\
\text { Eigenvalues } \\
\end{array}$} & \multicolumn{3}{|c|}{$\begin{array}{l}\text { Extraction Sums of } \\
\text { Squared Loadings }\end{array}$} & \multicolumn{3}{|c|}{$\begin{array}{l}\text { Rotation Sums of } \\
\text { Squared Loadings }\end{array}$} \\
\hline & $\begin{array}{l}\text { Total } \\
8.65\end{array}$ & $\begin{array}{c}\text { \% of Variance } \\
29.84\end{array}$ & $\begin{array}{c}\text { Cumulative \% } \\
29.84\end{array}$ & $\begin{array}{c}\text { Total } \\
5.17\end{array}$ & $\begin{array}{c}\text { \% of Variance } \\
17.84\end{array}$ & $\begin{array}{c}\text { Cumulative } \% \\
17.84\end{array}$ & $\begin{array}{l}\text { Total } \\
4.63\end{array}$ & $\begin{array}{c}\text { \% of Variance } \\
15.98\end{array}$ & $\begin{array}{c}\text { Cumulative } \% \\
15.98\end{array}$ \\
\hline
\end{tabular}

\section{Multicollinearity}

To inspect the issue of Multicollinearity variance inflation factor analysis was employed. Result of the test presented in Table 5, according to the figures VIF of all latent variable 
fluctuated between 1.1 to 4.5 which meet the threshold limit suggested by Obrien (2007). According to result it is proved that issue of Multicollinearity didn't exist in the model.

Table 5

VIF for latent and observable variables

\begin{tabular}{|c|c|c|c|c|c|c|c|}
\hline & EOU & INFO & PRSK & TRU & Z_ERESP & WEBB & UTBY \\
\hline EOU & & & & & 2.642 & & \\
\hline INFO & & & & & 2.293 & & \\
\hline PRSK & & & & & 4.564 & & \\
\hline TRU & & & & & 1.881 & & \\
\hline ERESP & & & & & & 1 & \\
\hline WEBB & & & & & & & 1.154 \\
\hline UTBY & & & & & & & 1.154 \\
\hline
\end{tabular}

\section{Structural Model}

Structural model was run to estimate the structural paths between endogenous and exogenous variables. Total 7 hypothesis were tested which supported at the sig value less than 0.01.Results of measurement model are displayed in Table 6 and Figure 2. Figures shows that, $\mathrm{H1}$ :ease of use has positive and significant influence on emotional response $(\beta=.170, \mathrm{p}<.01)$, informativeness has positive and significant influence on emotional response $(\beta=.246, \mathrm{p}<.01)$, and H4: perceived trust has positive and significant influence on emotional response $(\beta=.148, \mathrm{p}<.01)$, all these three hypothesis were supported. Likewise, H3: perceived risk exert negative and significant influence on emotional response $(\beta=-.670, \mathrm{p}<.01)$ was also supported, however it proved the negative relationship of perceived risk with emotional response. Furthermore, result revealed that H5: emotional response has positive and significant impact on web browsing $(\beta=.441, \mathrm{p}<.01)$ was supported, along with H6: emotional response has positive and significant influence on urge to buy impulsively $(\beta=.797, \mathrm{p}<.01)$, and web browsing has positive and significant influence on urge to buy impulsive $(\beta=.262, \mathrm{p}<.01)$, these both hypothesis were also supported.

Table 6

Testing of Structural Model

\begin{tabular}{lcccc}
\hline & Estimate & S.E. & C.R. & P \\
\hline H1: EOU $\rightarrow$ ERES & 0.17 & 0.033 & 7.159 & 0.006 \\
H2: INF $\rightarrow$ ERESP & 0.246 & 0.469 & 2.243 & 0.005 \\
H3: PRSK $\rightarrow$ ERESP & -0.67 & 0.052 & -6.842 & $* * *$ \\
H4: PTRU $\rightarrow$ ERESP & 0.148 & 0.032 & 5.952 & $* * *$ \\
H5: ERESP $\rightarrow$ WEBB & 0.441 & 0.135 & 4.876 & $* * *$ \\
H6: ERESP $\rightarrow$ UTBY & 0.797 & 0.129 & 10.069 & $* * *$ \\
H7: WEBB $\rightarrow$ UTBY & 0.262 & 0.05 & 4.101 & $* * *$ \\
\hline Note: CMIN $=410.738$, CMIN $/$ df $=1.215, \mathrm{p} \leq 0.004 ;$ \\
df $=338$, GFI $=.918$, AGFI $=.902$, NFI $=.891$, CFI $=.979$, \\
RMSEA $=0.026$
\end{tabular}


Figure 2

Structural model

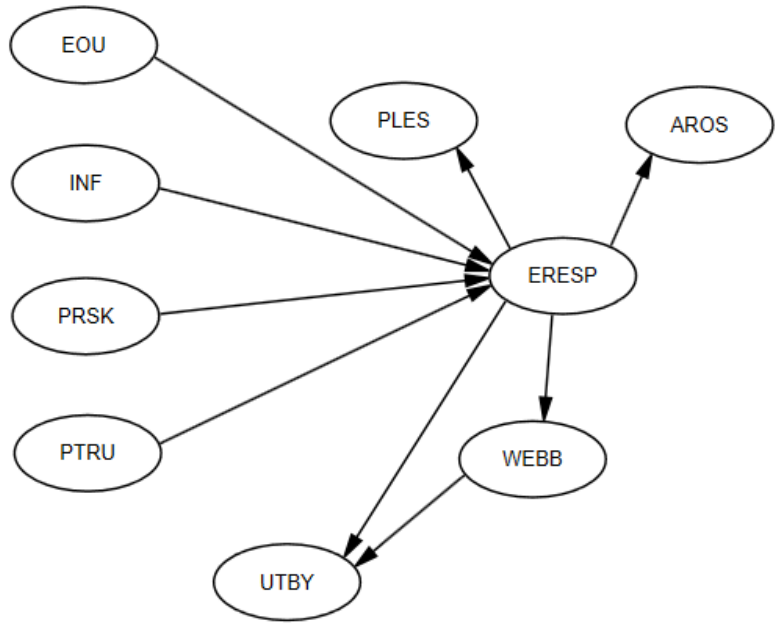

\section{Discussion}

This research investigated empirical model that explains how website's features such as ease to use, informativeness perceived risk and perceived trust on online shopping store exert effects on the emotional response of the online shopper and erase urge to by impulsively. These results are consistent with the studies of Richard and Chebat (2016); Mallapragada, Chandukala, and Liu (2016); Rezaei et al. (2016). Findings of the study revealed that easiness and simplicity of the online shopping web-stores such as easy navigation and organized online store positively contributes in developing customer emotional responses such as pleasantness of the mood and arousal, on the other hand if an online website shopping is difficult customer will apparent to have less pleasantness in the shopping which results the unfavorable emotional response. Furthermore, facts and figures also verified that informativeness of online shopping websites such as availability of all necessary information and knowledge on the website for the customer also positively contributes in the emotional response of online consumer.

Results also revealed that perceived risk plays a major role in shaping online purchaser's emotional response which designate that if an online shoppers have high perceived risk related to online shopping they have disinclinations toward online marketspace, in this regard online supermarkets should provide complete assurance to the customer that shopping on such stores is risk free and personal information of the online buyers will not be misused, in return customers will develop the feeling of low risk which contribute in the emotional pleasantness and positive emotional arousal and in case online sellers fail to do so the result will be unfavorable emotional response by the online buyers. Study results also demonstrated that perceptions about trust significantly predicts 
customer's emotional response, customers of online stores with high trust toward online seller comprehend more favorable inclinations about such trustworthy online retailers. Afterward, statistical indicators ascertained that positive emotional response such as pleasantness and favorable emotional arousal of online shoppers primarily develop urge to buy online impulsively which means that if a customer have affirmative emotional response toward online seller which is the result of mainly low perceived risk, higher trust, easiness of use and informative of the online web-store cause the online impulse buying.

Moreover, analysis result also shown that positive emotional response of the customer also make customer to spend more time on web browsing which is also become reason of online impulse buying which deduced that customer having delighted feeling spend longer time on online brewing and will be more intended to make online impulse purchases. According to the overall results of the study online venders should must considered the aspect of customer emotional response for inclining the customers to make online impulse buying which can be develops by reducing risk associated with online shopping, developing trust and designing easy and informative websites of online stores.

\section{Limitations and Future Recommendations}

While this research has a valuable contributions, this study has some notable limitations that should be consider before generalizing the findings. First the reliability and validity of perceived risk and urge to buy impulsively is just acceptable. Therefore, future research should replicate this model by using other measures of these constructs. Second this study was conducted with the help of online survey. A filed study or experimental context (e.g. use of e-coupons; Lin and Lo (2016)) may present better insight a better insight of the phenomenon. Student sample is used in this study as a subject of the study future research may consider other sample and online setting to increase the generalizability of this study. Finally future research can also consider some other variables for instance situation variables (money and time), trait affect and pre-shopping tendencies that may affect impulsive buying behavior. Furthermore, operationalization of web browsing into hedonic web browsing and utilitarian web browsing (Rezaei et al., 2016) may also offer some useful findings as for some products impulsive buying is because of hedonic drivers while in other it may be due to utilitarian drivers. 


\section{References}

Adelaar, T., Chang, S., Lancendorfer, K. M., Lee, B., \& Morimoto, M. (2003). Effects of media formats on emotions and impulse buying intent. Journal of Information Technology, 18(4), 247-266.

Amos, C., Holmes, G. R., \& Keneson, W. C. (2014). A meta-analysis of consumer impulse buying. Journal of Retailing and Consumer Services, 21(2), 86-97.

Anderson, J. C., \& Gerbing, D. W. (1988). Structural equation modeling in practice: A review and recommended two-step approach. Psychological Bulletin, 103(3), 411423.

Badgaiyan, A. J., \& Verma, A. (2015). Does urge to buy impulsively differ from impulsive buying behaviour? Assessing the impact of situational factors. Journal of Retailing and Consumer Services, 22, 145-157.

Bellini, S., Cardinali, M. G., \& Grandi, B. (2017). A structural equation model of impulse buying behaviour in grocery retailing. Journal of Retailing and Consumer Services, 36, 164-171.

Brashear, T. G., Kashyap, V., Musante, M. D., \& Donthu, N. (2009). A profile of the internet shopper: Evidence from six countries. Journal of Marketing Theory and Practice, 17(3), 267-282.

Chan, T. K., Cheung, C. M., \& Lee, Z. W. (2017). The state of online impulse-buying research: A literature analysis. Information $\mathcal{E}$ Management, 54(2), 204-217.

Chih, W.-H., Wu, C. H.-J., \& Li, H.-J. (2012). The antecedents of consumer online buying impulsiveness on a travel website: Individual internal factor perspectives. Journal of Travel \& Tourism Marketing, 29(5), 430-443.

Chung, N., Song, H. G., \& Lee, H. (2017). Consumers impulsive buying behavior of restaurant products in social commerce. International Journal of Contemporary Hospitality Management, 29(2), 709-731.

Dawson, S., \& Kim, M. (2009). External and internal trigger cues of impulse buying online. Direct Marketing: An International Journal, 3(1), 20-34.

Dholakia, U. M., Bagozzi, R. P., \& Pearo, L. K. (2004). A social influence model of consumer participation in network-and small-group-based virtual communities. International Journal of Research in Marketing, 21(3), 241-263.

Floh, A., \& Madlberger, M. (2013). The role of atmospheric cues in online impulse-buying behavior. Electronic Commerce Research and Applications, 12(6), 425-439.

Groeppel-Klein, A. (2005). Arousal and consumer in-store behavior. Brain Research Bulletin, 67(5), 428-437.

Hair, J., Black, W., Babin, B., Anderson, R., \& Tatham, R. (2013). Multivariate data analysis. Pearson Education Limited.

Haq, M. A., Abbasi, S., et al. (2016). Indirect impact of hedonic consumption and emotions on impulse purchase behavior: A double mediation model. Journal of Management Sciences, 3(2), 108-122.

Hausman, A. (2000). A multi-method investigation of consumer motivations in impulse buying behavior. Journal of Consumer Marketing, 17(5), 403-426. 
Hsu, C.-L., Chang, K.-C., \& Chen, M.-C. (2012). Flow experience and internet shopping behavior: Investigating the moderating effect of consumer characteristics. Systems Research and Behavioral Science, 29(3), 317-332.

Hubert, M., Hubert, M., Florack, A., Linzmajer, M., \& Kenning, P. (2013). Neural correlates of impulsive buying tendencies during perception of product packaging. Psychology $\mathcal{E}$ Marketing, 30(10), 861-873.

Koufaris, M. (2002). Applying the technology acceptance model and flow theory to online consumer behavior. Information Systems Research, 13(2), 205-223.

Lin, S.-W., \& Lo, L. Y.-S. (2016). Evoking online consumer impulse buying through virtual layout schemes. Behaviour E Information Technology, 35(1), 38-56.

Liu, Y., Li, H., \& Hu, F. (2013). Website attributes in urging online impulse purchase: An empirical investigation on consumer perceptions. Decision Support Systems, 55(3), 829-837.

Lucas, M., \& Koff, E. (2017). Body image, impulse buying, and the mediating role of negative affect. Personality and Individual Differences, 105, 330-334.

Mallapragada, G., Chandukala, S. R., \& Liu, Q. (2016). Exploring the effects of what(product) and where(website) characteristics on online shopping behavior. Journal of Marketing, 80(2), 21-38.

Merzer, M. (2014). Survey: 3 in 4 Americans make impulse purchases. Retrieved from http://www.creditcards.com/credit-card-news/impulse -purchase-survey.php

Mittal, S., Chawla, D., \& Sondhi, N. (2016). Impulse buying tendencies among Indian consumers: Scale development and validation. Journal of Indian Business Research, 8(3), 205-226.

Ning Shen, K., \& Khalifa, M. (2012). System design effects on online impulse buying. Internet Research, 22(4), 396-425.

Obrien, R. M. (2007). A caution regarding rules of thumb for variance inflation factors. Quality $\mathcal{E}$ Quantity, 41(5), 673-690.

Parboteeah, D. V., Valacich, J. S., \& Wells, J. D. (2009). The influence of website characteristics on a consumer's urge to buy impulsively. Information Systems Research, 20(1), 60-78.

Park, E. J., Kim, E. Y., Funches, V. M., \& Foxx, W. (2012). Apparel product attributes, web browsing, and e-impulse buying on shopping websites. Journal of Business Research, 65(11), 1583-1589.

Park, H. J., \& Dhandra, T. K. (2017). Relation between dispositional mindfulness and impulsive buying tendency: Role of trait emotional intelligence. Personality and Individual Differences, 105, 208-212.

Park, J., \& Lennon, S. J. (2006). Psychological and environmental antecedents of impulse buying tendency in the multichannel shopping context. Journal of Consumer Marketing, 23(2), 56-66.

Pornpitakpan, C., Yuan, Y., \& Han, J. H. (2017). The effect of salespersons' retail service quality and consumers' mood on impulse buying. Australasian Marketing Journal (AMJ), 25(1), 2-11.

Rezaei, S., Ali, F., Amin, M., \& Jayashree, S. (2016). Online impulse buying of tourism 
products: The role of web site personality, utilitarian and hedonic web browsing. Journal of Hospitality and Tourism Technology, 7(1), 60-83.

Richard, M.-O., \& Chebat, J.-C. (2016). Modeling online consumer behavior: Preeminence of emotions and moderating influences of need for cognition and optimal stimulation level. Journal of Business Research, 69(2), 541-553.

Ruvio, A. A., \& Belk, R. W. (2013). The routledge companion to identity and consumption. Routledge.

Sekaran, U., \& Bougie, R. (2016). Research methods for business: A skill building approach. John Wiley \& Sons.

Sethi, V., \& King, W. R. (1994). Development of measures to assess the extent to which an information technology application provides competitive advantage. Management Science, 40(12), 1601-1627.

Sharma, P., Sivakumaran, B., \& Marshall, R. (2010). Impulse buying and variety seeking: A trait-correlates perspective. Journal of Business Research, 63(3), 276-283.

Tehseen, S., Ramayah, T., Sajilan, S., et al. (2017). Testing and controlling for common method variance: A review of available methods. Journal of Management Sciences, $4(2), 142-168$.

Turkyilmaz, C. A., Erdem, S., \& Uslu, A. (2015). The effects of personality traits and website quality on online impulse buying. Procedia-Social and Behavioral Sciences, 175, 98-105.

Verhagen, T., \& van Dolen, W. (2011). The influence of online store beliefs on consumer online impulse buying: A model and empirical application. Information $\mathcal{E}$ Management, 48(8), 320-327.

Verplanken, B., \& Sato, A. (2011). The psychology of impulse buying: An integrative self-regulation approach. Journal of Consumer Policy, 34(2), 197-210.

Vonkeman, C., Verhagen, T., \& van Dolen, W. (2017). Role of local presence in online impulse buying. Information \& Management, 54(8), 1038-1048.

Wells, J. D., Parboteeah, V., \& Valacich, J. S. (2011). Online impulse buying: understanding the interplay between consumer impulsiveness and website quality. Journal of the Association for Information Systems, 12(1), 32-56.

Wu, L., Chen, K.-W., \& Chiu, M.-L. (2016). Defining key drivers of online impulse purchasing: A perspective of both impulse shoppers and system users. International Journal of Information Management, 36(3), 284-296. 